\title{
CORRELATION STUDY ON PHYSICO-CHEMICAL AND PHYTOPLANKTON DYNAMICS OF RIVER NILE AT FAYOUM GOVERNORATE
}

\author{
Hanan A. Said and Mai M. Hassan \\ Botany Department, Faculty of Science, Fayoum University
}

\begin{abstract}
The diversity of phytoplankton and its relationships to the physico-chemical parameters were investigated in River Nile. The study area of the River Nile is located in Fayoum Governorate. Samples were collected monthly from October 2011 to September 2012, from the intake of seven drinking water treatment plants to a large extent cover the stream of River Nile branches in Fayoum governorate. The results of physic-chemical characteristics reveled that fluctuation in temperature between seasons was highly detected with respect to different seasons. In addition, results show no clear variation in $\mathrm{pH}$ values between different months or between different sites, where statistical analysis showed that no significant correlations between $\mathrm{pH}$ and phytoplankton count $(\mathrm{r}=-0.40)$. Also, in this investigation correlation analysis showed no significant correlation between total algal count and nitrate and total phosphorus concentration $(r=0.30$ and $r=0.34$ respectively). Furthermore, results of phytoplankton community structure showed that fifty four species in five divisions of phytoplankton were found. The greatest number of species were in division Chlorophyta (40.7\%), followed by Bacillariophyta $(33.3 \%)$, Cyanophyta (18.5\%), Euglenophyta (5.6\%) and Pyrrophyta (1.9\%).
\end{abstract}

Key words: River Nile, Freshwater, phytoplankton, physic-chemical characteristics, community structure.

\section{Introduction}

Phytoplankton is assemblages of heterogeneous microscopic algal forms whose movement is more or less dependent upon water currents. Study of planktonic diversity contributes to understanding of the environmental status of a water body and, therefore, it may be used as an indicator of water quality (Lund and Talling, 1957; Sreenivasan, 1976; Reynolds, 1984, Gujaria and Kumar, 1992, Ravikumar et al. 2006, Tsai and Gonulal, 2007, Sivakumar and Senthilkumar, 2008; Bhartikhare and PramodPatil, 2011; Rani and Sivakumar, 2012). Phytoplanktons form the vital source of energy as primary 
producers and serves as a direct source of food to the other aquatic plants and animals.

Increased human activities have significantly contributed to the pollution and toxicity of aquatic ecosystems. Pollutants bring changes not only in the physical and chemical quality of water but also result in a variety of alterations in the biological integrity of aquatic systems (Simo-Matchim et al., 2016).

The traditional physico-chemical measurements used in water quality monitoring programs provide a good indication of the quality of aquatic systems, but they do not the ecological state of the system (Karr et al., 2000).Biological assessment is a useful alternative for assigning the ecological quality of aquatic ecosystems since biological communities integrate the environmental effects of water chemistry in addition to the physical and geomorphological characteristics of rivers and lakes (Stevenson and Pan, 1999).

The River Nile forms the main water resource of Egypt. The High Dam construction resulted in great modification in the hydrodynamic regime of the River Nile, with significant changes in physico-chemical and biological characteristics of the downstream water (Ramadan and Shehata, 1976; Saad and Goma, 1994; Shehata et al., 1995; Shehata et al., 1997; Abdel-Shafy and Aly 2002; Fishar and Khalifa, 2003; Shehata et al., 2008). The river is known to be subjected to contamination by wastes derived from industrial sources, sewage and agricultural activities that alter the physico-chemical and biological properties and ecology of the biotic environment. Therefore, the present study is an attempt to record the changes in the community structure of phytoplankton in the River Nile in Fayoum governorate in relation to the physic-chemical characteristics.

\section{Materials and Methods}

\section{Sampling Site}

Fayoum is one of the 29 Governorates of Egypt. It lies about $90 \mathrm{~km}$ southwest of Cairo and has an area of $6,069 \mathrm{~km}^{2}$. Nile floodwater reaches the Fayoum depression through the Hawara (Lahun) gap, where the altitude is about $25 \mathrm{~m}$ above sea level. Bahr Youssef canal that feeds the entire irrigation and drinking water system of the governorate passes through this gap. Bahr Youssef Canal is a branch of Ibrahimeya Canal, which originates from Dayrout (Assiut Governorate). 
In Fayoum water works intakes locate on Bahar Youssef canal and its branches. In this investigation Seven sampling sites were chosen (Fig.1), intake of New El-Azab water works $\left(S_{1}\right)$, intake of Old El-Azab water works $\left(S_{2}\right)$, intake of Quhafa water works $\left(\mathrm{S}_{3}\right)$, intake of Abo-Gandir water works $\left(\mathrm{S}_{4}\right)$, intake of ElRayan water works $\left(\mathrm{S}_{5}\right)$ and the mixing point on Bahr El-Banat $\left(\mathrm{S}_{6}\right)$ and intake of Tamia water works $\left(\mathrm{S}_{7}\right)$. The water source of Tamia water works comes directly from the Nile through $15 \mathrm{Km}$ long pipes come from (Gerza- El- Ayatt) to the plant.

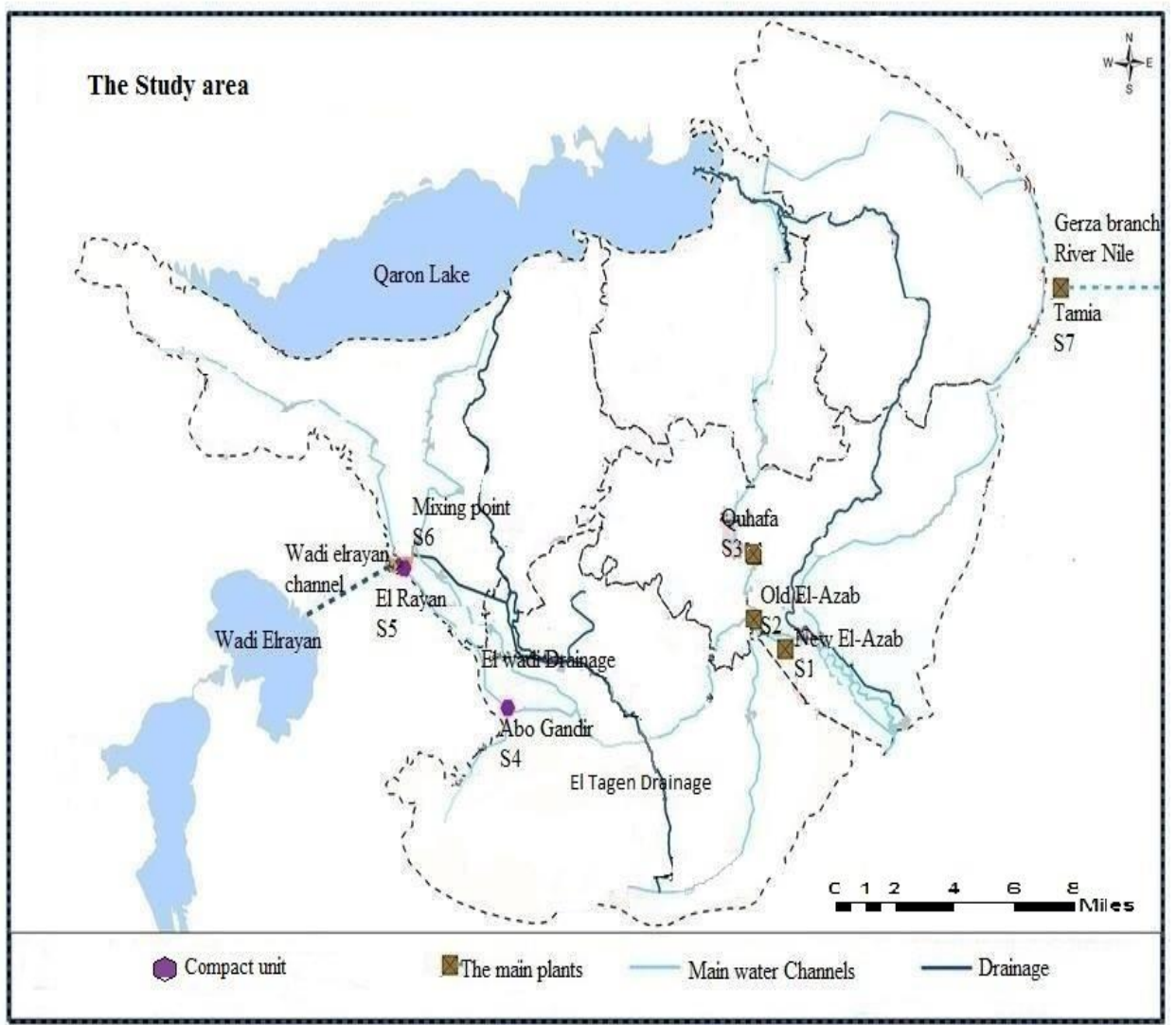

Figure (1): The study area and location of the sampling sites 


\section{Physio-chemical Water analysis}

Water samples for chemical and biological analysis were collected at monthly intervals of a period (October 2011-September 2012). Determinations of the physico-chemical characteristics involves the temperature, $\mathrm{pH}$, turbidity, electric conductivity (EC), total dissolved solids (TDS), dissolved oxygen, total alkalinity, total hardness, calcium and magnesium hardness, chloride, sulfate, ammonia, nitrate, nitrite, total phosphorus, silica, iron and manganese. The Standard Methods, recommended by the APHA (2005) as followed.

\section{Biological water sample analysis}

\section{Sample collection}

Sub surface water samples were collected from the sampling sites by auto sampler in dark bottles for phytoplankton counting and chlorophyll a determination. The phytoplankton counting bottles contain lugol's solution for preservation, while chlorophyll a determination bottles contain magnesium carbonate solution for chlorophyll fixation. Samples stored at $4^{\circ} \mathrm{C}$.

\section{Sample concentration}

$500 \mathrm{ml}$ water sample was concentrated by sedimentation technique in cylindrical settling champers with thin, clear glass. The supernatant was siphoned carefully to obtain the desired net volume.

\section{Counting procedure}

$1 \mathrm{ml}$ concentrated sample transferred to Sedgwick-Rafter chamber and examined under up-right microscope.

\section{Calculación:}

$$
\text { No. } / \mathrm{ml}=\frac{C X 1000 \mathrm{~mm} 3}{A X D X F}
$$

Where:

$\mathrm{C}=$ number of organism counted, $\mathrm{A}=$ area of field $\mathrm{mm}^{2}, \mathrm{D}=$ depth of a field $\mathrm{mm}, \mathrm{F}=$ number of fields counted.

In addition, all the Phytoplankton were identified according to the following workers: (Geitler, 1932; Hustedt, 1976; Streble and Krauter, 1978; Komárek and Fott, 1983; Komárek and Anagnostidis, 1989). 


\section{Chlorophyll a measurement}

Chlorophyll a content of algal cells was extracted and measured according to APHA (2005).

\section{Results and Discussion}

The governorate of Fayoum lies within the Fayoum depression, which until recent times received floodwaters each from the Nile to the east and, like almost all of Egypt, still depends entirely on that river. This area has a unique physical setting, but also unique environmental and natural resource. Nile floodwater reaches the Fayoum depression through the Hawara (Lahun) gap, where the altitude is about $25 \mathrm{~m}$ above sea level. Bahar Youssef canal that feeds the entire irrigation and drinking water system of the governorate passes through this gap (Drinking water supply and sanitation programmed in Fayoum, Egypt, 19902009). Because of the connection with the natural Nile branch, it spreads its water through many meandering natural branches that still used as irrigation canals in inefficient way.

The hydrochemical properties of water during the time of investigation were recorded in (Table 1). The inter-correlation between various physicochemical parameters and phytoplankton is illustrated by (Figures 1-9) and Pearson correlation analysis (Table 2).

\section{Temperature:}

The fluctuation in temperature between seasons was highly detected with respect to different seasons in winter; the lowest temperature was $14^{\circ} \mathrm{C}$ while in summer the highest temperature was $33.1^{\circ} \mathrm{C}$. Temperature has a direct effect on the phytoplankton count where it reached the maximum in winter. Correlation analysis showed that temperature has a high negative correlation with phytoplankton count $(\mathrm{r}=-0.75)$ and chlorophyll a $(\mathrm{r}=-0.64)$.

\section{pH:}

The $\mathrm{pH}$ of all water samples emphasizes the alkaline characteristics of River Nile water where the $\mathrm{pH}$ value was in the range of 7.31 to 8.22. Results show no clear variation in $\mathrm{pH}$ values between different months or between different sites. Statistical analysis showed that no significant correlations between $\mathrm{pH}$ and phytoplankton count $(\mathrm{r}=-0.40)$. 


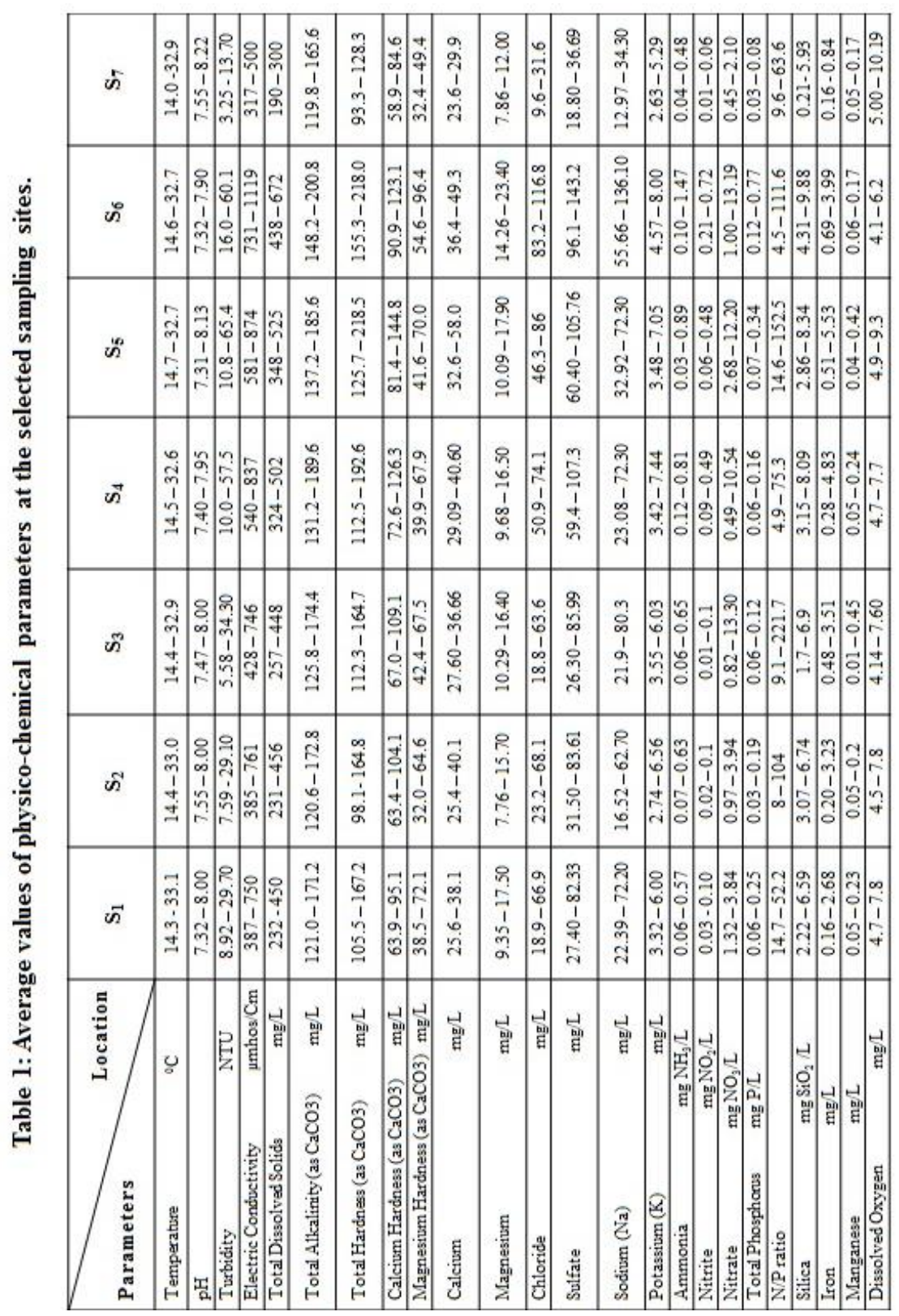


Table 2: Correlation between physicochemical parameters and algal density.

\begin{tabular}{|l|c|}
\hline \multicolumn{1}{|c|}{ Parameters } & Correlation coefficient \\
\hline Temperature $\left({ }^{\mathrm{O}} \mathrm{C}\right)$ & -0.75 \\
\hline $\mathrm{pH}$ & -0.40 \\
\hline Turbidity $(\mathrm{NTU})$ & -0.62 \\
\hline Nitrate $\left(\mathrm{mg} \mathrm{NO}_{3} / \mathrm{L}\right)$ & 0.30 \\
\hline Total Phosphorus $(\mathrm{mg} \mathrm{P} / \mathrm{L})$ & 0.34 \\
\hline Silica $\left(\mathrm{mg} \mathrm{SiO}_{2} / \mathrm{L}\right)$ & -0.60 \\
\hline Dissolved Oxygen $(\mathrm{mg} / \mathrm{L})$ & 0.61 \\
\hline Chlorophyll a $(\mu \mathrm{g} / \mathrm{L})$ & 0.71 \\
\hline \multicolumn{2}{|l|}{ Note. The critical values are $0.58,0.71$, and 0.82 for significance levels $0.05,0.01$, and 0.001 , respectively. }
\end{tabular}

\section{Turbidity:}

Results revealed that the turbidity of water samples could be classified into three levels 7.3-34.3 $\left(\mathrm{S}_{1}-\mathrm{S}_{3}\right)$, 9.9-65.4 $\left(\mathrm{S}_{4}-\mathrm{S}_{6}\right)$ and 3.2-13.7 $\left(\mathrm{S}_{7}\right)$. The variation in turbidity level between the selected sites is due to the variation in the water source where $S_{1}-S_{3}$ locate on the main stream of Bahar Youssef canal and $S_{4}-S_{6}$ locate on small branches of the canal.

The water source of $S_{7}$ comes directly from the Nile through $15 \mathrm{Km}$ long pipes come from (Gerza- El- Ayatt). Negative correlation was found between turbidity values and total algal count, this correlation confirmed by statistical analysis $(\mathrm{r}=-0.62)$.

\section{Dissolved Oxygen (DO):}

Dissolved oxygen is important for the survival of aquatic organisms and is used to evaluate the degree of freshness of a river (Agbaire and Obi, 2009).The WHO (World Health Organization) suggested the standard of DO is $>5 \mathrm{mgO}_{2} / \mathrm{L}$. In this investigation, the lowest value of dissolved oxygen of $4.1 \mathrm{mg} / \mathrm{L}$ was obtained in site $S_{6}$ and the highest value of $10.19 \mathrm{mg} / \mathrm{L}$ was obtained in site $S_{7}$. Dissolved oxygen in natural water depends on the physical, chemical and 
biological activities in the water body. Correlation analysis revealed significant positive correlation between total algal count and dissolved oxygen $(r=0.59)$, in contrast a significant negative correlation between dissolved oxygen and temperature illustrated by (Fig. 2) and also confirmed by correlation analysis ( $\mathrm{r}=$ $-0.67)$.

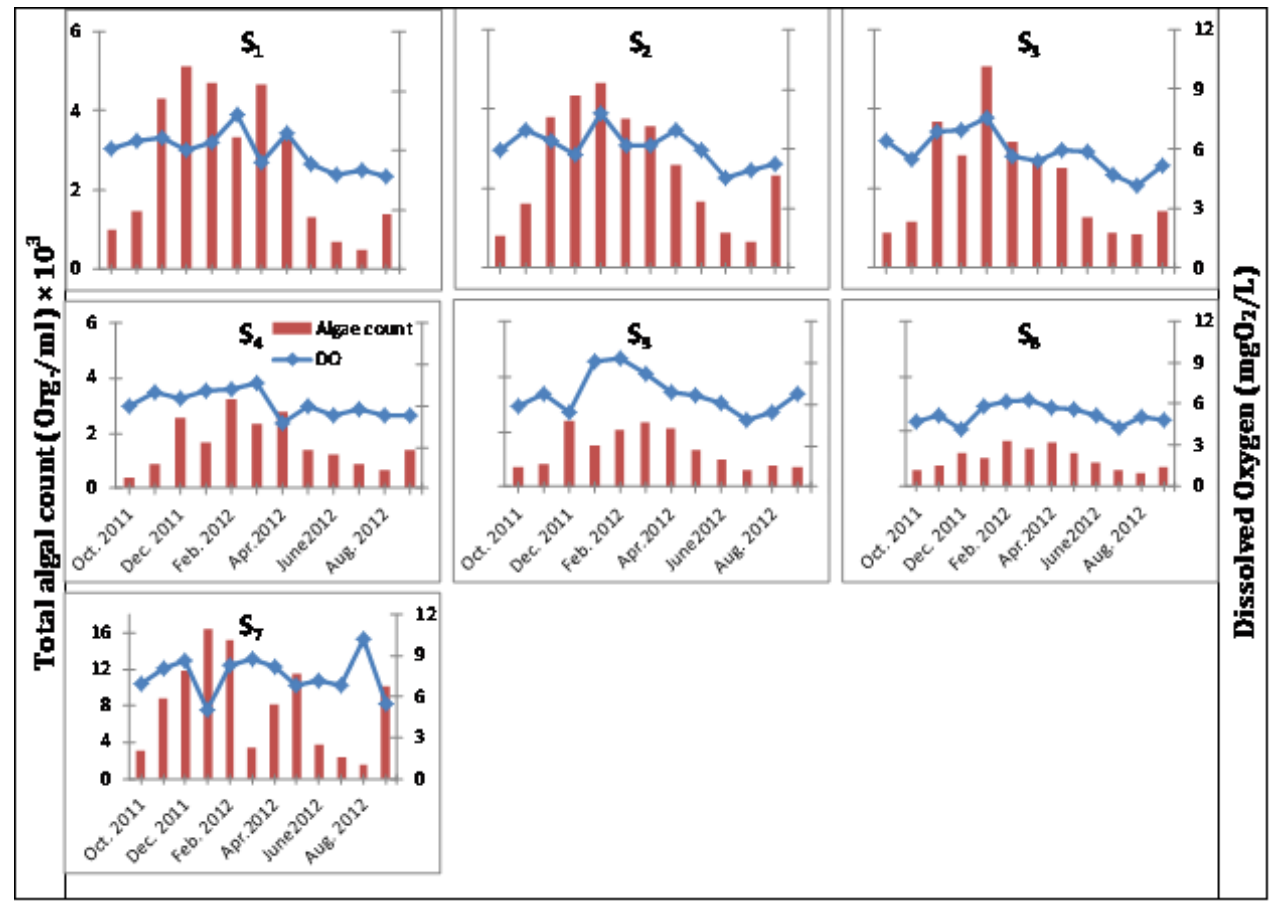

Figure (2): Relationship between total algal count and dissolved oxygen

\section{Nutrient:}

Nitrogen and phosphorus limit the growth of terrestrial plants, phytoplankton, macroalgae and vascular plants in fresh water and marine ecosystem (Rabalais, 2002; Abdo and El-Nasharty, 2010). Nitrogen in water occurs in various forms like nitrates, nitrites, ammonia and organic nitrogen. Nitrate is one of the most important indicators of pollution of water. According to Kumar and Ravindranath (1998) nitrate concentration of more than $5 \mathrm{mg} / \mathrm{L}$ in water, usually indicate pollution made by human and animal wastes or fertilizer 
runoff. The WHO (World Health Organization) standard drinking water quality guideline for nitrate $\left(\mathrm{NO}_{3}\right)$ value is $45 \mathrm{mg} / \mathrm{L}$. Phosphorus occurs in natural water almost solely as phosphates. The major source of inorganic phosphorus are domestic sewage, detergent, industrial and agricultural effluents.

Phosphate is considered to be the most significant among the nutrients responsible for eutrophication (Sushanth and Rajashekhar, 2012). Nutrient concentrations of River Nile water and its branches mainly Bahr Youssef which feed Fayoum Governorate with freshwater emphasize the spatial and temporal variation from site to site and from month to month. The same observation was detected with the N/P ratio that revealed a pronounced difference between maximum and minimum values in different sites and different month through the investigation. Since the N:P ratio 16:1 is maintained under maximal growth rates in nutrient poor waters, steady state conditions are established and therefore the $\mathrm{N}: \mathrm{P}$ ratio 16:1, also known as Redfield ratio, is considered as reference value. The relative constancy of the $\mathrm{N}: \mathrm{P}$ ratio of nutrients is determined by physiological rather than chemical processes. Decreased N:P ratio values indicates nitrogen limitation whereas, higher N:P ratios, potential phosphorus limitation (Redfield $\boldsymbol{e t}$ al., 1963). However, it has also been supported that these deviations from the typical N:P ratio values can also be linked to eutrophication problems. Changes of the N:P atomic ratio was first related to excessive phosphorus loads from sewage by Ryther and Dunstan (1971). In this investigation correlation analysis showed no significant correlation between total algal count and nitrate and total phosphorus concentration ( $r=0.30$ and $r=0.34$ respectively) (Table 2, Figures 3 and 4). 


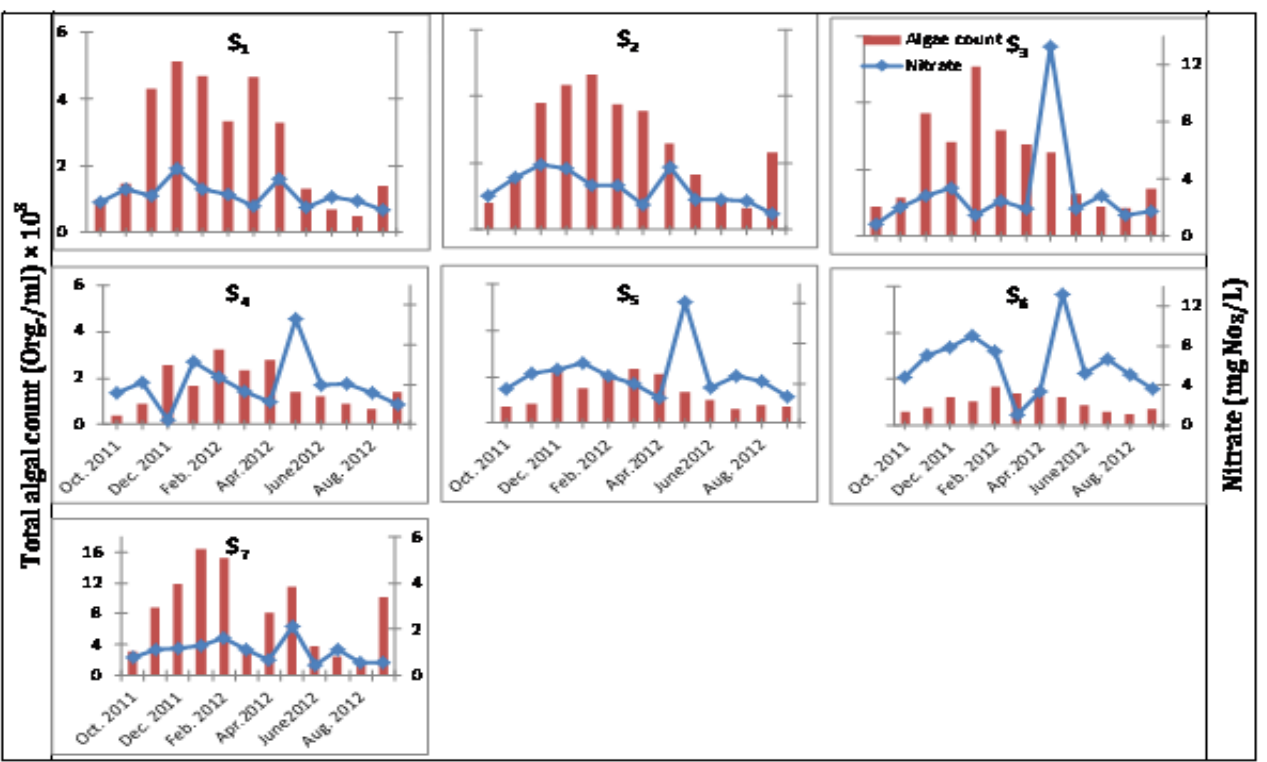

Figure (3): Relationship between total algal count and nitrate

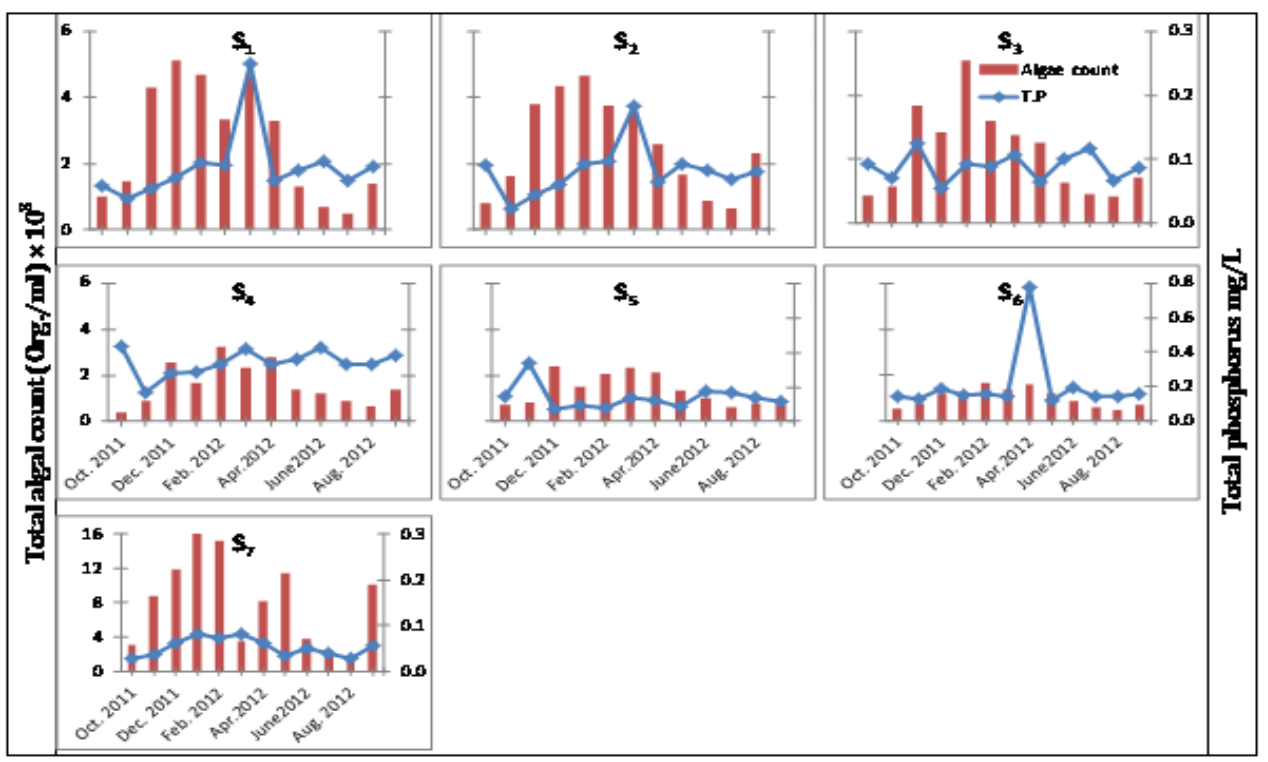

Figure (4): Relationship between total algal count and total phosphorus Egyptian J. of Phycol. Vol. 17, 2016 -60 - 


\section{Silica}

Dissolved silica is an important nutrient for formation the silica wall of diatoms (dominate phytoplankton assemblages). Concentration of dissolved silica ranged between $0.21-9.88 \mathrm{mg} \mathrm{SiO}_{2} / \mathrm{L}$. The lowest values were associated with the maximum growth of diatoms (Fig. 5). This correlation confirmed statistically ( $\mathrm{r}$ $=0.60)$.

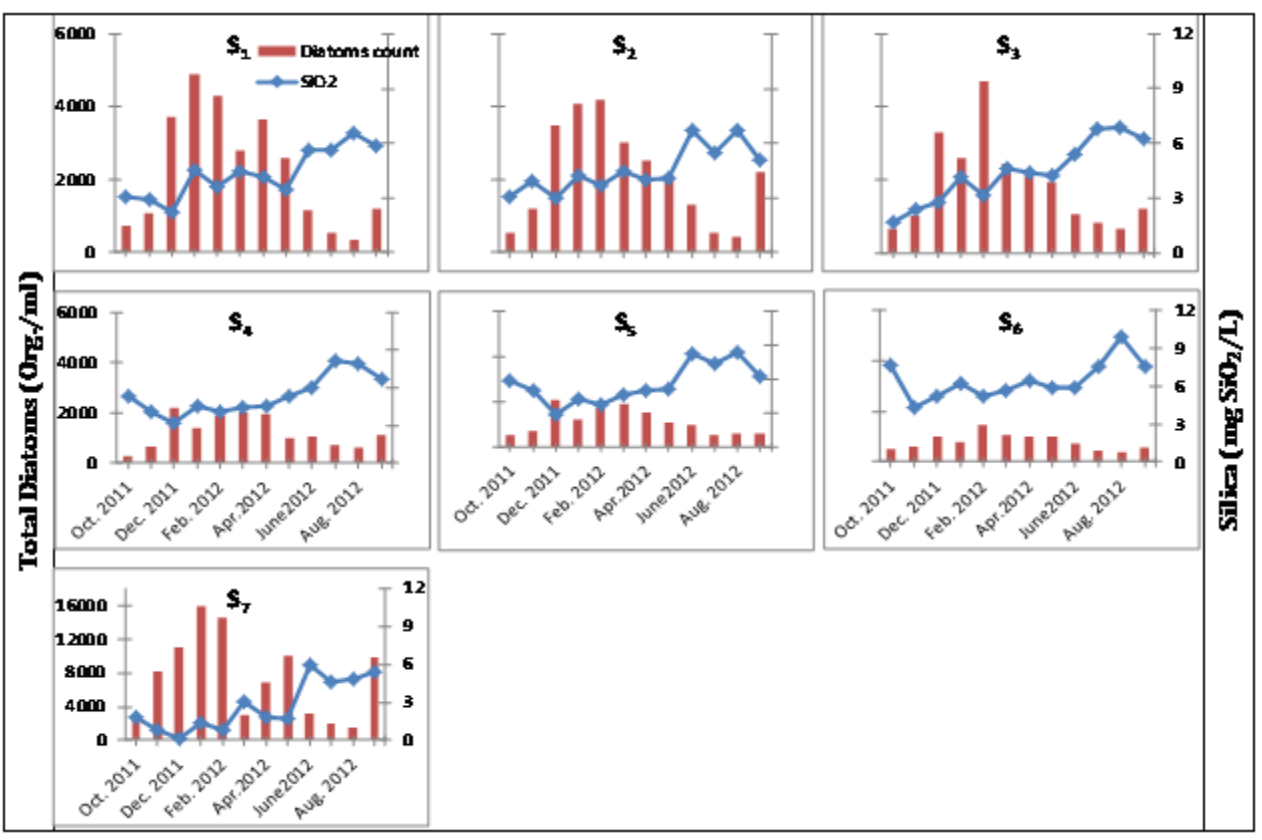

Figure (5): Relationship between total diatom count and silica

\section{Chlorophyll "a" content}

Chlorophyll "a" content ranged from $0.20-17.53 \mu \mathrm{g} / \mathrm{L}$. Clear relationship between phytoplankton numbers and chlorophyll "a" content were established (Fig. 6). Statistical analysis showed that positive correlation of Chl. "a" with total algal counts $(\mathrm{r}=0.71)$. Simo-Matchim et al. $(\mathbf{2 0 1 6})$ stated that the highest values of primary production and Chl. a biomass were measured during the summer bloom, and those high values indicate that highly productive ecosystems. 


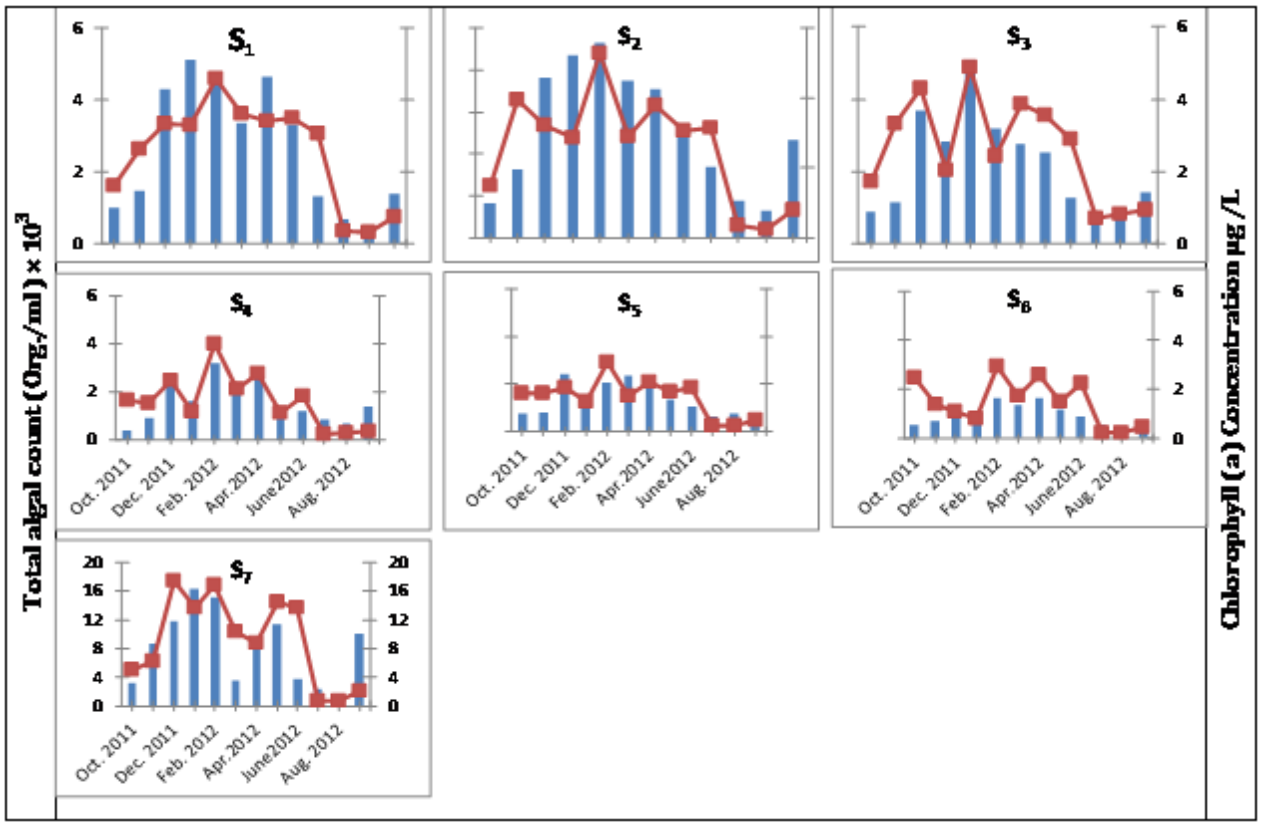

Figure (6): Relationship between total algal count and Chlorophyll (a).

\section{Phytoplankton}

In the present study, the phytoplankton community in of River Nile that reached to Fayoum Governorate through Bahr Youssef Canal and in front of drinking water treatment was represented by members of Chlorophyceae, Bacillariophyceae, Cyanophyceae, Euglenophyceae and Pyrrophytaceaeas represented in (Table 3). A total of 54 algal species can be identified, of which 22 species belonging to Chlorophyta, 18 belonging to Bacillariophyta, 10 belonging to Cyanophyta, 3 belonging to Euglenophyta and only one for Pyrrophyta. The percent composition of phytoplankton is illustrated by (Fig. 7). All the sampling sites were quite similar in community composition as well as the diversity and dominance of different algal group. Quantitative analysis of phytoplankton populations showed that it reached its maximum value during winter and spring months (Fig. 8). In the present study, quantitative analysis of phytoplankton populations showed that the abundance of diatoms group was detected in all sites 


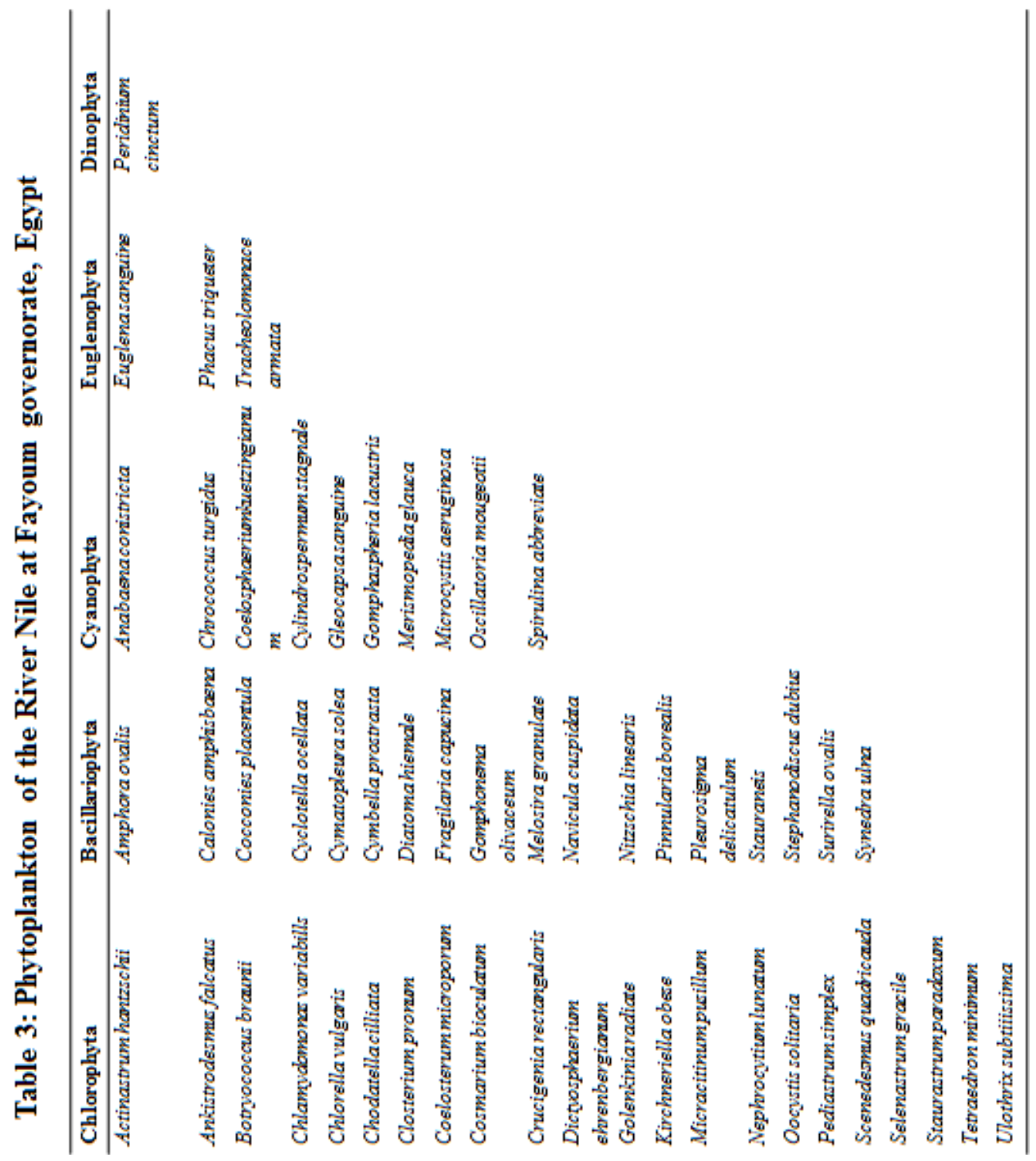




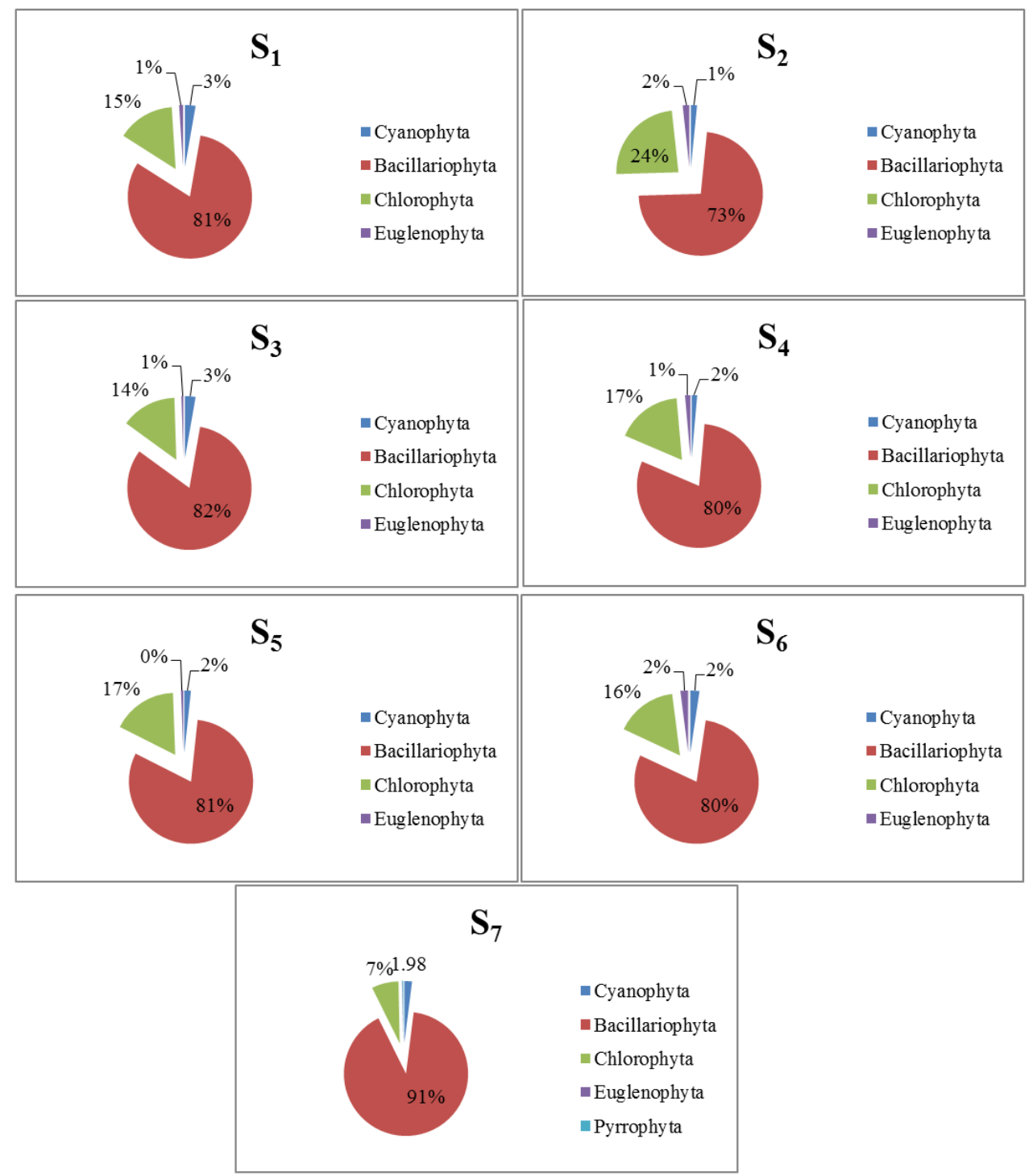

Figure (7): The percent composition of different phytoplankton groups at the selected study sites 


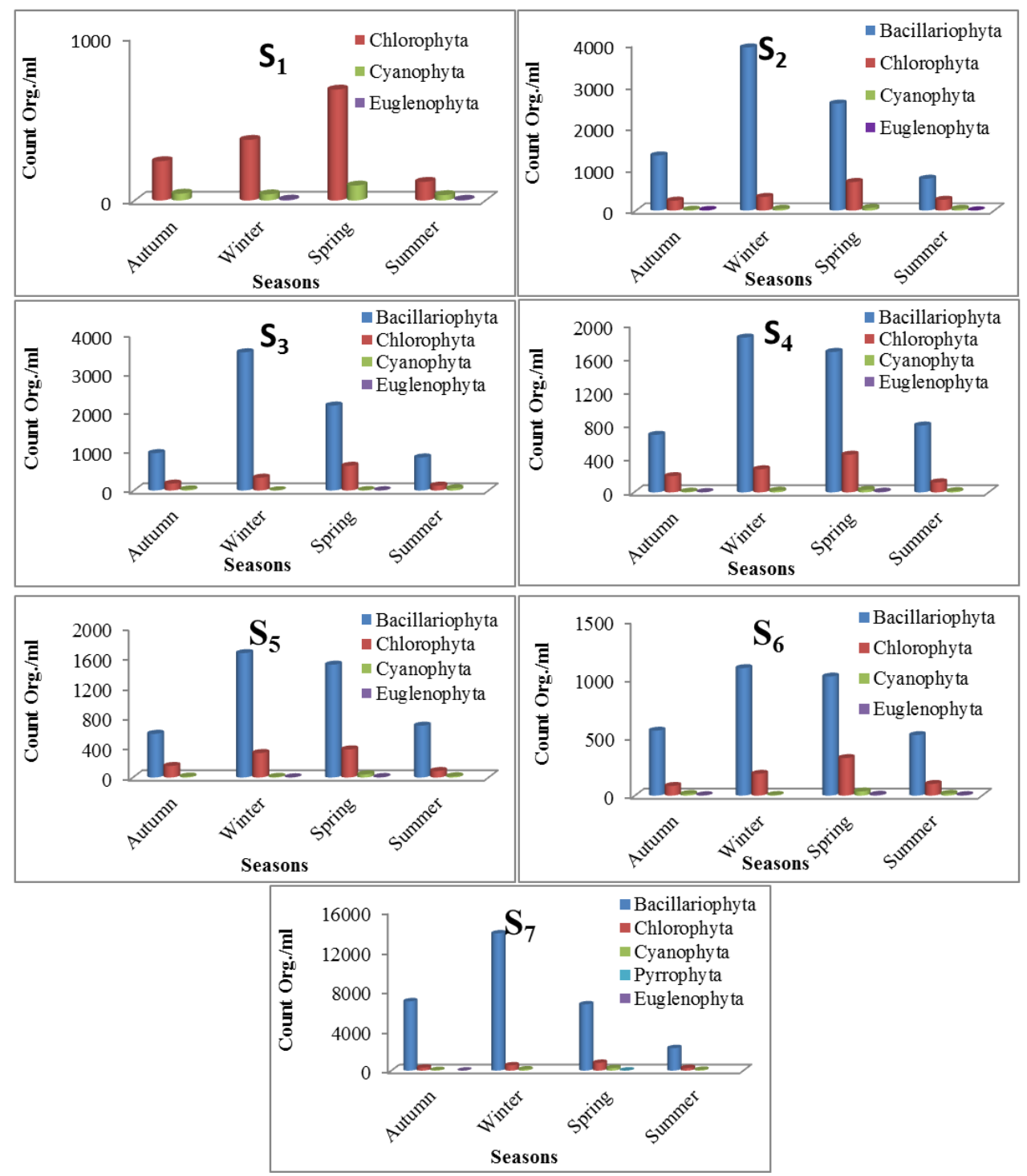

Figure (8): Seasonal Variation densities of different phytoplankton groups at the selected study sites 
and along the time of investigation. The numerical superiority represented by species of Cyclotella ocellata, Melosira granulate, Synedra ulna, Cocconies placentula, Stephanodiscus dubius, Nitzschia linearis and Navicula cuspidate. Simo-Matchim et al. (2016) found that a mixed assemblage of diatoms and flagellates in summer, whereas the fall community was largely dominated by flagellates. Water temperature affects the abundance of diatoms. Most diatoms are suited to cold water, but if the temperature is too low, it will suppress the growth (Wim and Koen, 1995).

Furthermore, the present investigation established a considerable diversity in members of green algal group where it represented by 22 species in all sites. Many green algae such as Scenedesmus quadricauda, Pediastrum simplex, Ankistrodesmus falcatus, Staurastrum paradoxum, Tetraedron minimum and Chlamydomonas variabills are occurred abundantly and frequently. In addition blue-green algae are represented by species of Microcystis aeruginosa, Merismopedia glauca, Chrococcus turgidus, Oscillatoria mougeotii and Spirulina abbreviate. Species belonging to Euglenophyta and Pyrrophyta are Euglena sanguine, Phacus triqueter, Tracheolomonace armata and Peridinium cinctum. Hence, the most pollution-tolerant species such as Euglena, Oscillatoria, Navicula, Nitzschia, Ankistrodesmus, Scenedesmus and Chlamydomonas were recorded to be present in all sites and along different season of investigation. Palmer (1969); Gunale and Balakrishnan (1981) and Jafari and Gunale (2006) reported that genera like Oscillatoria, Euglena, Scenedesmus, Chlamydomonas, Navicula, Nitzschia, Stigeoclonium, and Ankistrodesmus are the species found in organically polluted waters. Further, Kumar et al. (2012) found that the planktonic forms of Pandorina, Scenedesmus, Navicula, Chlorella, Spirulina, Anabaena, Eudorina, Melosira, Closterium and Cosmarium were observed as indicators of organic pollution-tolerant species. Microcystis aeruginosa is associated with the highest degree of civic pollution (Shekhar $\boldsymbol{e t}$ al., 2008) and may be considered as the best single indicator of organic pollution in any water body. River Nile water revealed slight change in physic-chemical characteristics such as $\mathrm{pH}$, turbidity, total dissolved solids, alkalinity, total hardness, chloride, sulphate as well as nutrient content (nitrate, phosphate and silica) especially at all sites involved in this investigation. In addition, SimoMatchim et al. (2016) found that seasonal variations in phytoplankton dynamics were mainly controlled by the strength of the vertical stratification and by the large differences in day length. The pronounced change can be observed in temperature during different season where it fluctuated between $14^{\circ} \mathrm{C}$ in winter 
months to $33^{\circ} \mathrm{C}$ in summer months, this result obtained in different sites. So, the fluctuation in algal abundance and algal count can be attributed to the effect of temperature on algal species. Suresh et al. (2011) stated that variations of water temperature were well marked with respect to different seasons and it plays an important role in controlling the abundance of phytoplankton (Singh, 1960). Also, Simo-Matchim et al. (2016) confirmed that a marked seasonal variability, with significant differences in phytoplankton structure and function between summer and fall, while the $\mathrm{pH}$ of water may promotes the growth of algae (Geroge, 1961 and Suresh et al., 2013).

\section{Conclusion}

1. Based on the present study phytoplankton density, community structure, and physicochemical characters of River Nile water was satisfactory and suitable for human consumption and other domestic uses.

2. Algal numbers may change in the raw Nile water according to the time and season of the year in addition to the site of sample collection. Therefore, analysis should be conducted over yearly cycles.

3. Dominance and diversity of algal species in aquatic ecosystem specify the quality of the ecosystem to different human uses.

4. Study algal community structure of aquatic ecosystem is a key factor in determining water treatment technology used in Drinking Water Treatment Plant.

5. The presence of different algal groups with high numbers during various seasons in the river Nile has led to a re-evaluation of traditional treatment technologies.

\section{Dedication}

To the sole of Professor Dr./ Refaat M. Ali for his encouragement and help during all lab work.

\section{Acknowledgment}

The authors are grateful to Prof. Dr./ Gamila H. Ali, Water Pollution Department, National Research Centre, Cairo, Egypt for her keen support and valuable comments, suggestions and sincere help in preparation of manuscript and also for her reviewing this manuscript. 


\section{References}

Abdel-Shafy, H.I. and Aly, R.O. (2002). Water Issues in Egypt: Resources, Pollution and Protection Endeavors. Central European J. Occupational and Environmental Medicine, 8(1): 3-21.

Abdo, M.H. and El-Nasharty, S.M. (2010). Physico-Chemical Evaluation and Trace Metals Distribution in Water Surfiacial Sediment of Ismailia Canal, Egypt. Nature and Science, 8(5):198-206.

Agbaire, P.O. and Obi, C.G. (2009). Seasonal Variation of Some PhysicoChemical Properties of River Ethiope Water in Abraka, Nigeria. J. Appl. Sci. Environ. Manag., 13(1): 55-57.

American Public Health Association (APHA) (2005). Standard Methods for the Examination of Water and Wastewater. APHA, AWWA, WPCE, N. Y. Washington. 541 pp.

Simo-Matchim, A.; Gosselin, M.; Blais, M.; Gratton, Y. and Tremblay, J. (2016). Seasonal Variations of Phytoplankton Dynamics in Nunatsiavut fjords (Labrador, Canada) and Their Relationships with Environmental Conditions. Journal of Marine Systems, 156: 56-75.

Bharti, K. and Pramod, P. (2011). Aquatic Biodiversity of Cyanophytes of JawaharBal Udayan Pond, Bhopal. Indian Hydrobiol., 14: 8-21.

Fishar, M.R.A. and Khalifa, U.S.A. (2003) (eds). Status of Biodiversity of River Nile, Workshop hold at British Council, 9 December, Cairo, Egypt. 80pp.

Geitler, L. (1932). Cyanophyceae. In Rabenhorst's Kryptogamenflora von Deutschland, Österreich und der Schweiz. (R. Kolkwitz, ed.). Akademische. Verlagsgesellschaft, Leipzig, 14:1-1196.

George, M.G. (1961). Diurnal Variations in Two Shallow Ponds in Delhi, India, Hydrobiologia, 18(3): 265-273.

Gujaria, S.C. and Kumar, H. (1992). Physico-Chemical and Biological Characterization of Fish Pond of Kenjrav Fish Pond II. $15^{\text {th }}$ Indian Bot. Confer. Aurangabad.

Gunale, V.R and Balakrishnan, M.S. (1981). Biomonitoring of Eutrophication in the Pavana, Mula and Mutha Rivers Flowing Through Poona. Ind. J. Environ. Health, 23: 316-322. 
Hustedt, F. (1976). Die Süsswasser-Flora Mitteleuropas. Heft 10: Bacillatiophyta (Diatomeae). Otto Koelz Science Publishers, D- 6240 Koenigstein, Germany.

Jafari, N.G. and Gunale, V.R. (2006). Hydrobiological Study of Algae of an Urban Freshwater River. J. Appl. Sci. Environ. Mgt., 10(2): 153-158.

Karr, J.R.; Allen, J.D. and Benke, A.C. (2000). River Conservation in the United States and Canada. In: Boon PJ, Davies BR, Petts GE, eds. Global Perspectives on River Conservation. Science, Policy and Practice. Wiley, Chichester, pp.3-39.

Komárek, J.T. and Anagnostidis, K. (1989). Cyanoprokaryota. IChroococcales, Süsswasserfl ora von Mitteleuropa, 19/1. G. Fischer, Stuttgart.

Komárek, J.T. and Fott, B. (1983). Das Phytoplankton des SüBWasser, Systematik und Biologie. Peil 7, 1Hälfte, Chlorophyceae (Grünalgen) Ordnung Chlorococcales. Stuttgart, 1044 pages.

Kumar, S.M. and Ravindranath, S. (1998). Water Studies - Methods for Monitoring Water Quality. Published by Center for Environment Education (CEE), Banglore, Karnataka, India, pp: 191.

Kumar, R.N.; Solanki, R. and Kumar, J.I. (2012). Spatial Variation in Phytoplankton Diversity in the Sabarmati River at Ahmed Abad, Gujarat, India. Annals of Environmental Science, 6:13-28.

Lund, J. W. and Tailling, J. F. (1957). Botanical and Limnological Methods with Special Reference to The Algae. Bot. Rev., 231: 489-533.

Palmer, C. M. (1969). A Composite Rating of Algae Tolerating Organic Pollution. Journal of Phycology, 5(1):78-82.

Rabalais, N. N. (2002). Nitrogen in Aquatic Ecosystems, $A M B I O$, 31(2):102-122.

Ramadan, F.M. and Shehata, S.A. (1976). Early Changes in Phytoplankton of Nile Water (1965-1974). Symposium on Nile Water and Lake Dam Projects. National Research Center, Cairo, March, 1-4.

Rani, R. and Sivakumar, K. (2012). Physico-Chemical Parameters and Phytoplankton Richness in Certain Ponds of Chidambaram, Cuddalore District of Tamil Nadu. International Journal of Research in Environmental Science and Technology, 2(2): 35-44. 
Ravikumar, M.; Manjapppa, S.; Kiran, B.R. and Puttaiah, E.T. (2006). Phytoplankton Periodicity in Relation to Abiotic Factors in Kulahalli Tank near Harapanehalli, Karnataka. Nat. Environ. Poll. Technol., 5(1): 157-161.

Redfield, A.C.; Katchum, B.H. and Richards, S.A. (1963). The Influence of Organisms on The Composition of Seawater, In: The Sea, vol. 2, M. N. Hill (Ed.) John Wily and Sons, New York, pp. 26- 67.

Reynolds, C.S. (1984). The Ecology of Freshwater Phytoplankton. Cambridge University Press, Cambridge and New York. 384p.

Ryther, J.H. and Dunstan, W.M. (1971). Nitrogen, Phosphorus and Eutrophication in the Coastal Marine Environment. Science, 171(3975):1008-1013.

Saad, M.A.H. and Goma, R.H. (1994). Effects of the High Dam and Aswan Cataract on the Chemical Composition of the Nile Water. I. Major Anions. Verh. Internat.Verein. Limnol., 25:1812-1815.

Shekhar, T.R.; Kiran, B.R.; Puttaiah, E.T.; Shivaraj, Y. and Mahadevan, K.M. (2008). Phytoplankton as Index of Water Quality with Reference to Industrial Pollution. J. Environ. Biol., 29 (2): 233-236.

Shehata, S.A.; Badr, S.A. and Wahba, S.Z. (1997). Phytoplankton Composition of the River Nile at the Intake of El-Giza Waterworks. Egyptian J. App. Sci., 12(12): 389-412.

Shehata, S. A.; Ali, Gamila H. and Wahba, S.Z. (2008). Distribution Pattern of Nile Water Algae with Reference to its Treatability in Drinking Water. $J$. Appl. Sci. Res., 4(6): 722-730.

Shehata, S.A.; Lasheen, M.R.; Badr, S.A. and Ashmawy, A.A. (1995). Seasonal Variation in Phytoplankton Diversity and Metals in Sediments of River Nile, Cairo, Egypt. J. App. Sci., 10(7): 573-587.

Singh, V.P. (1960). Phytoplankton ecology of the inland waters of Uttar Pradesh, Proc. Symp Algae ICAR, New Delhi, pp. 243-271.

Sivakumar, K. and Senthilkumar, R. (2008). Biodiversity of microalgae and their elemental components from Veeranam Lake, Tamil Nadu, India. Korean J. Limnol., 2: 128-136.

Sreenivasan, A. (1976). Limnological studies and primary production in temple pond ecosystem. Hydrobiol., 48, 117-123.

Egyptian J. of Phycol. Vol. 17, $2016 \quad$ - 70 - 
Stevenson, R.J.; Pan, Y. and Van Dam, H. (1999). Assessing environmental conditions in rivers and streams with diatoms. The diatoms: applications for the environmental and earth sciences (ed. by E.F. Stoermer and J.P. Smol), Cambridge University Press, Cambridge. pp. 57-85.

Streble, H. and Krauter, B. (1978). Das LebenimWassertropfen. Mikroflora und Mikrofauna des Subwasser, EinBestimmungsbuchmit 1700 Abbildungen. Stuttgart. 398pp.

Suresh, B.; Manjappa, S. and Puttaiah, E.T. (2011). Phytoplankton dynamics and seasonal variation in Tungabhadra River, India. International Journal of Water Resources and Environmental Engineering , 3(14):370-379.

Suresh, B.; Manjappa, S. and Puttaiah, E.T. (2013). Dynamics of phytoplankton succession in Tungabhadra River near Harihar, Karnataka (India). Journal of Microbiology and Antimicrobials, 5(7):65-71.

Sushanth, V.R. and Rajashekhar, M. (2012). Seasonal variation in diatoms in response to physico-chemical characteristics of coastal waters of Uttara Kannada district, West Coast of India. International Journal of environmental sciences, 2(3):1543-1552.

Tasi, B. and Arif, G. (2007). An ecological and taxonomic study on phytoplankton of a shallow lake. Turkey J. Environ. Biol., 28: 439-445.

Wim, V. and Koen, S. (1995). Diatom-temperature transfer functions based on the altitudinal zonation of diatom assemblages in Papua New Guinea: a possible tool in the reconstruction of regional palaeoclimatic changes, Journal of Paleolimnology, 13:65-77. 


\title{
دراسة توافقية على الخواص الفيزيائية و الكيميائية و العوالث النباتية لنهر النيل بمحافظة الفيوم
}

\author{
حنان عبد الله سعيد ، مى مصطفى حسن

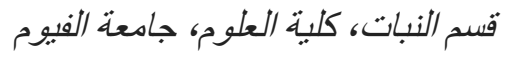

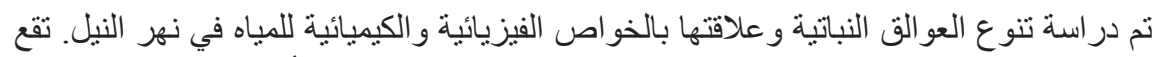

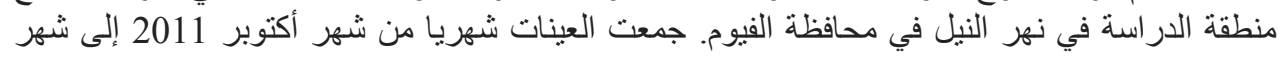

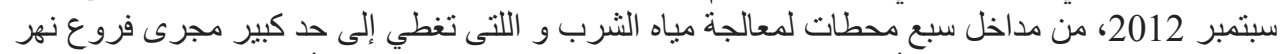

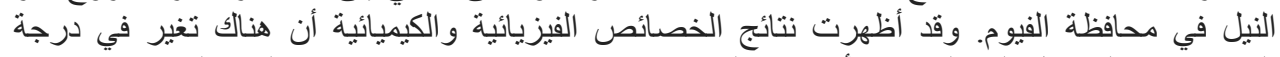

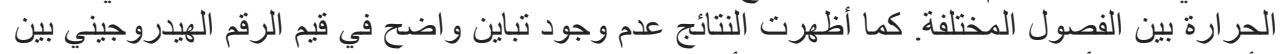

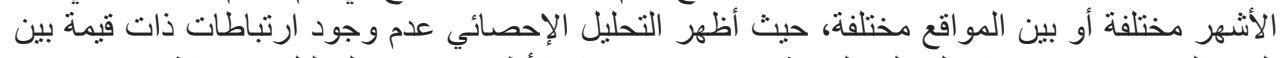

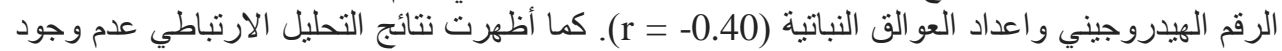

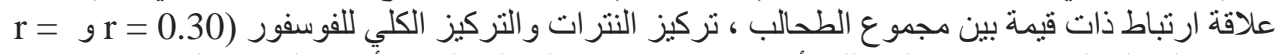

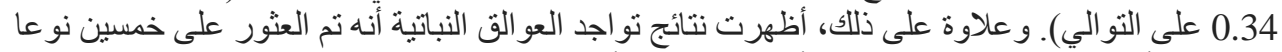

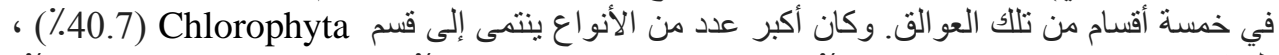

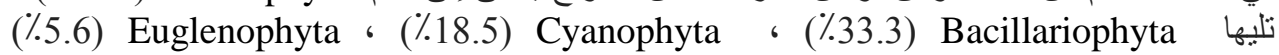
. (\%1.9) Pyrrophyta 